\title{
A Comparative Investigation of Assessment Practices in Distance and Online Learning Undergraduate Mathematics in Nigeria
}

\author{
Comfort O. Reju, PhD \\ University of Lagos, Lagos, Nigeria \\ Loyiso C. Jita, PhD \\ University of the Free State, Bloemfontein, South Africa
}

Contact: creju@unilag.edu.ng

\section{Abstract}

We investigate and compare assessment practices in two (dual- and single-mode) institutions in Nigeria. A mixed-methods approach was employed. Descriptive statistics and narration were carried out for the purpose of determining what the assessment practices were and how they may be related to the students learning of undergraduate mathematics in distance and online education. Results show that there are similarities and variations in assessment practices that shaped open and distance learning practices in these universities. This suggests a need for careful review of assessment practices aimed at improving students' engagement and learning for outstanding undergraduate mathematics learning experiences.

Keywords: assessment practices; feedback; students experiences; distance and online learning; undergraduate mathematics

Date Submitted: July 18, 2019 | Date Published: May 26, 2020

\section{Recommended Citation}

Reju, C. O., \& Jita, L. C. (2020). A comparative investigation of assessment practices in distance and online learning undergraduate mathematics in Nigeria. Journal of Educational Research and Practice, 10, 90-103. https://doi.org/10.5590/JERAP.2020.10.1.06

\section{Introduction}

The introduction of distance and online learning in higher education teaching and learning has developed considerably in the 21th century (Baleni, 2015). The trend that brought about the online learning platform, for example, Learning Management System to offer online/interactive learning, and assessment has led to a greater use of computer technology to facilitate learning. Studies have shown that despite the advancement in distance and online education across institutions of higher learning, assessment of online courses (including mathematics) still progresses at a slow pace (Yushau \& Khan, 2014). Assessment as a vital component of learning in distance and online education gives the teacher better opportunity to monitor the students' learning, skills, and certification (Chaudhary \& Dey, 2013; Perera-Diltz \& Moe, 2014). The educational progress of the students can be monitored by the instructor, thereby allowing the learners to conduct selfassessment to become self-directed learners. Kissane et al. (2015) pointed out that the availability of 
technology and its use in mathematics education changes the way assessment is carried out in undergraduate mathematics learning; hence, "current assessment practices are struggling to keep pace with the use of technology for doing and teaching mathematics" (Stacey \& Wiliam, 2013, p. 721). Suurtamm et al. (2016) clarified some important conceptual principles necessary for sound distance and online mathematics assessment of students. These include assessments containing high-quality mathematics that guarantee learning and ensure equitable students learning opportunities and should be transparent enough to allow conclusions to be made (p. 4).

The purpose of this comparative case study is to examine and compare the current assessment practices among a dual-mode delivery university (Distance Learning Institute [DLI], University of Lagos) and a singlemode delivery university (National Open University of Nigeria [NOUN]). The concern pertinent to this article is what the assessment practices are and how they may be related to the students learning of undergraduate mathematics in distance and online education. This article is based on the results from doctoral research at the University of the Free State, South Africa (Reju, 2016). It was a 2-year study (from 2014 to 2016) based on students' experiences with distance and online learning of university-level undergraduate mathematics in Nigeria. Two open and distance learning (ODL) institutions were extensively studied; closed- and open-ended questionnaires and semistructured interviews were used as instruments for data collection.

\section{Literature Review}

The increased demands for higher education and technological advancement have led to improvement witnessed in institutional effective and efficient distance and online course delivery (Trenholm et al., 2015). Assessment as an essential part of distance and online instructional delivery has been defined as procedures that provide information about the learning quality and the present knowledge of the learners (American Mathematical Association of Two-Year Colleges, 2018). The distance and online learning assessment does not only influence the content the learners spend time on but also influences the type of learning they engage themselves in; at the same time, it is valued as the main influence of quality of learning and also serves as a means to monitor and evaluate the learner (Camacho-Miñano et al., 2013; U.S. Department of Education, Office of Educational Technology, 2017). Stacey and Wiliam (2013) reported that distance and online students explore mathematical knowledge themselves by formulating, testing, and solving problems; hence, the pressure in assessment using technologies may have to be reduced for them to show their mathematical ability.

Studies on distance and online assessment from different countries conclude that assessment as a key element in formal higher education has a very strong impact on learning and also serves as strategic matter for universities with the purpose of providing information about students learning progress (Baleni, 2015; Camacho-Miñano et al., 2013; U.S. Department of Education, Office of Educational Technology, 2017). For the students to produce constructive learning practice, the learning must be assessment centered in presenting the students with the opportunity to demonstrate their abilities. That is, educational progress of the learners is monitored by instructors and the learners can conduct self-assessment that is self-directed. Ozerbas and Erdogan (2016) argued that a student learning in distance and online mode needs to possess selfefficacy necessary in achieving online assessment goals. Assessment attracts independent practices prominent to mathematical self-efficacy among distance and online learners. Studies have shown that assessment practices affect students' concentration on the tasks and course materials they believe that can be assessed to provide useful evidence to the institution (Suurtamm et al., 2016). Hence, the National Education Policy (The Ministry of Human Resources Department, 2019) proposed a strong adaptive assessment that will enable the instructors evaluate the learners learning progress and offer accurate feedback. The researchers, Morris (2008) and Suurtamm et al. (2016) further pointed out the importance of assessment to include providing regular and exact feedback to the students, modifying course content or delivery methods based on the assessment and feedback received from students, students acting on the feedback of the instructors and doing 
the assessment at their convenience. According to Kissane et al. (2015), institutions are responsible for their own assessment practices, "which are expected to provide credible evidence against the standards associated with each course" (p. 36). Hence, any assessment method or strategy is required to align with distance and online teaching and learning from the beginning of a course material design and development.

Studies have shown that due to reliability and validity of the online assessment, educational providers in general and distance and online educators in particular, have accepted the assessment of students using technologies as efficient and effective (Baleni, 2015; Yushau \& Khan, 2014). It has also been reported that students have a positive view of online assessment (Sorensen, 2013; Yushau \& Khan, 2014). Sagarraa and Zapataa (2008) pointed out some features of online assessment that have positive influence on mathematics students to include the provision of opportunity for multiple attempts, students working at their own pace, getting prompt feedback on work done and in some cases, have opportunity to access correct answer on submission of work. Trenholm and colleagues (2015) conducted a comprehensive research on assessment and feedback practices in fully asynchronous online undergraduate mathematics courses. Their findings from the study indicated that despite the emphasis on feedback, there is no evidence that it advances students mathematics learning. There is also the claim that lack of time to do an online assessment, slow Internet access, issues related to learning platform, and slowness of the system are the major challenges of online mathematics assessment (Yushau \& Khan, 2014).

It has been noted that some research works on distance and online assessment are based on "Student Success: Stimulating Student Achievement in Mathematics" and "Online Formative Assessment in Higher Education: Its Pros and Cons and Computer-Assisted Assessment” (Baleni, 2015; Bull \& McKenna, 2004; American Mathematical Association of Two-Year Colleges, 2018). This study stemmed from a few similar assumptions on distance and online assessment practices and mathematics students' experiences but specifically provides an extension in comparing single and dual mode ODL assessment practices. From the study, it becomes evident that in addition to the different mode of ODL institution used, there exist specific congruent and incongruent experiences of assessment practices among the distance and online undergraduate mathematics students in these universities. Hence, to detect these practices, we considered the mode of assessment and how it relates to students' mathematics experiences.

\section{Methodology}

This study employed mixed methods and comparative approaches aimed at exploring and comparing the current assessment practices from two (dual- and single-mode delivery) universities in Nigeria. The quantitative research approach was used to determine the assessment practices in the ODL institutions involved in the study; qualitative approach explores the phenomena (assessment practices) as a whole and comparison were made on the two ODL institutions to explore the facts (Creswell, 2014). The comparison was strictly based on the assessment practices and no effort was made to match the structures of the universities.

\section{Participants}

The participants in this study were third-year undergraduate degree mathematics education students in ODL (DLI and NOUN) institutions. There were about 38 third-year mathematics education students in DLI at the time this study was conducted. The study centers were located within the University of Lagos main campus and students attend biweekly meetings organized by the institute. NOUN, on the other hand, has close to 80 third-year mathematics education students in three study centers located in different parts of Lagos. Only 40 or fewer students attend the voluntary weekly study center meetings as observed and revealed by the students support officer during data collection visits. These universities were chosen owing to the widely diverse students' background, experiences in offering distance and online courses and widespread of these students' 
Reju \& Jita, 2020

representation across the country. These institutions though have slight differences in the mode of instruction, but they display model of ODL experiences and practices in Nigeria useful for this study.

Based on the population of the third year mathematics education students in these institutions, a nonprobabilistic sampling technique (purposive sampling) was conveniently used to select a total of 60 learners (DLI $n=30$; NOUN $n=30$ ) to participate in the study as volunteers (Cohen et al., 2007). The use of purposive sampling technique in this study helps to ensure only mathematics education students in these universities and level were selected. The students were approached during the visit to their schools to participate and were invited to take part in the study. The 60 third-year undergraduate mathematics students from both (DLI and NOUN) universities who consented to participate in the study filled out a paper-based closed and open-ended questionnaire consisting of twelve-question items plus fill-in the gap items of the designed questionnaire. A total of 10 students who filled the questionnaire was sampled for the interviews. The instruments were described in the next session. A total of $70 \%$ of the participants from DLI were males and $30 \%$ were females; $83.3 \%$ of the participants from NOUN were males and $16.7 \%$ were female.

\section{Instruments}

Mixed methods (questionnaire and interviews) were used as a means of gathering data and for an in-depth investigation of the construct. The initial guideline in the formulation of instruments to measure assessment practices in e-learning experiences was obtained from the Course Experience Questionnaire (CEQ) of Ramsden (1991). The Ramsden CEQ consists of good teaching, clear learning goals, appropriate workloads, and appropriate assessment. Based on these, the instrument for this study was formulated by adapting and modifying an item (appropriate assessment) from CEQ to suit the study environment and reflect the students' experiences with assessment practices. The closed questions were answered using a 5-point Likert scale, while the open-ended questions involved filling in the blanks. The interviews and open-ended questions were employed with the feeling that closed questions alone may not be enough in capturing the views of the students. Experts in the curriculum, distance and online educator and a university committee where the study was carried out were engaged to explore the validity of the instruments. Triangulation of data collection on both institutions (DLI and NOUN) and piloting of the instruments $(N=8)$ on students who were different but with a similar character with those used in the study were done to determine the reliability of the instruments. The results from the pilot study appeared to indicate there is an internal consistency based on the responses of the participants.

\section{Data Analyses}

The study employed a sequential explanatory design to determine the current assessment practices and how they shape the experiences of distance and online undergraduate mathematics learners. The analyses are presented in tables below according to the responses of the students from the ODL institutions (DLI and NOUN). The descriptive statistics and frequency analysis were carried out on the CEQ and these were for the purpose of determining what the assessment practices are and how they may be related to the students learning of undergraduate mathematics in distance and online education. The students' responses were captured using a 5-point Likert scale rating of 1 (strongly disagree), 2 (disagree), 3 (neutral), 4 (agree), and 5 (strongly agree). The mean upper cut-off point used in this study was 3.50, while the lower point was 2.50. This indicated that any response with a mean score of 3.50 or above is regarded as agree, otherwise, it disagrees. Open-ended questions were included in the questionnaire. The students' responses to open-ended questions (being asked to briefly explain the mode of assessment practices in their institutions) and the interviews were transcribed word-for-word to generate codes, subcategories, categories and themes which were analysed narratively (Elo \& Kyngäs, 2008). The mixed-method approach was used to obtain the students' opinions and expressions for more in-depth and meaningful details of assessment practices in these ODL institutions. 
Reju \& Jita, 2020

\section{Results}

This section examines students' responses to the 12 items of the appropriate assessment questionnaire adapted from Ramsden's (1991) CEQ. Tables 1 and 2 identify differently the important current assessment practices in DLI and NOUN. Table 3 shows the comparisons of the assessment practices of the ODL institutions used in the study. The means and standard deviations are given, along with the with percentages for each response.

Table 1 focuses on the responses of DLI students on assessment practices. The means of the items are as follows: "Assessment procedures are well specified and included in the design of mathematics course materials" ( $M=3.47)$, "lack of adequate resources to support student assessment procedures" $(M=2.93)$, "assessment guiding principles not well understood by the students" $(M=2.87)$, "online assessment not the only form of assessment procedure used in my institution" $(M=2.43)$, "access to online assessment procedures very easy" ( $M=3.20)$, "I enjoy doing mathematics assessment online" $(M=2.60)$, "assessment feedback is promptly obtained online" $(M=2.87)$, and "distance and online assessment procedures in my institution are very effective" ( $M=2.90)$. The selected items above were relatively low with mean scores less than 3.50. The assertion of Stacey and Wiliam (2013) and Yushau and Khan (2014) that current assessment practices for doing and teaching mathematics through technology are still struggling and progresses at a slow pace is therefore supported by our study. On the other hand, the students agreed that their institution uses online and traditional assessment procedures in assessing the mathematics distance learners $(M=3.60)$. Similarly, the students' high responses for "it is better to use online and traditional procedures to assess distance and online mathematics students" $(M=3.97)$ indicate that the students recognize the importance of blended approach in ODL mode of assessment that might increase their mathematical understanding if effectively used. Nevertheless, the preference for traditional methods of assessment as opposed to online assessment $(M=3.90)$ indicates that traditional forms of assessment persist and are preferred among most distance and online mathematics learners as indicated in Table 1. 
Table 1. Responses of Distance Learning Institute Students as Related to Assessment Practices

\begin{tabular}{|c|c|c|c|c|c|c|c|}
\hline Questionnaire item & $\begin{array}{l}\text { Strongly } \\
\text { disagree }\end{array}$ & Disagree & Neutral & Agree & $\begin{array}{c}\text { Strongly } \\
\text { agree }\end{array}$ & $M$ & $S D$ \\
\hline $\begin{array}{l}\text { 1. Assessment procedures are well } \\
\text { specified and included in the design } \\
\text { of mathematics course materials in } \\
\text { my institution. }\end{array}$ & $1(3.3)$ & $5(16.7)$ & $5(16.7)$ & $17(56.7)$ & $2(6.6)$ & 3.47 & 0.97 \\
\hline $\begin{array}{l}\text { 2. There are no adequate resources to } \\
\text { support student assessment } \\
\text { procedures. }\end{array}$ & $2(6.6)$ & $11(36.8)$ & $6(20.0)$ & $9(30.0)$ & $2(6.6)$ & 2.93 & 1.11 \\
\hline $\begin{array}{l}\text { 3. The guiding principle on } \\
\text { mathematics assessment is not well } \\
\text { understood by the students. }\end{array}$ & $12(40)$ & & $11(36.8)$ & $6(20.0)$ & $1(3.3)$ & 2.87 & 0.86 \\
\hline $\begin{array}{l}\text { 4. The students' assessment guidelines } \\
\text { involve too much paperwork (i.e., the } \\
\text { traditional method of assessment) } \\
\text { compared to distance and online } \\
\text { activities. }\end{array}$ & $2(6.6)$ & $10(33 \cdot 3)$ & $5(16.7)$ & $11(36.8)$ & $2(6.6)$ & 3.03 & 1.13 \\
\hline $\begin{array}{l}\text { 5. Online assessment of mathematics } \\
\text { students is the only form of } \\
\text { assessment procedure used in my } \\
\text { institution. }\end{array}$ & $3(10.0)$ & $16(53.4)$ & $7(23.3)$ & $3(10.0)$ & $1(3.3)$ & 2.43 & 0.94 \\
\hline $\begin{array}{l}\text { 6. My institution uses online and } \\
\text { traditional assessment procedures in } \\
\text { assessing the mathematics distance } \\
\text { learners. }\end{array}$ & $1(3.3)$ & $5(16.7)$ & $3(10.0)$ & $17(56.7)$ & $4(13 \cdot 3)$ & 3.60 & 1.04 \\
\hline $\begin{array}{l}\text { 7. I prefer traditional methods of } \\
\text { assessment as opposed to online } \\
\text { assessment. }\end{array}$ & $3(10.0)$ & & $5(16.7)$ & $14(46.6)$ & $8(26.7)$ & 3.90 & 0.92 \\
\hline $\begin{array}{l}\text { 8. It is better to use online and } \\
\text { traditional procedures to assess } \\
\text { distance and online mathematics } \\
\text { students. }\end{array}$ & $1(3.3)$ & $1(3.3)$ & $4(13 \cdot 3)$ & $16(53.4)$ & $8(26.7)$ & $\mathbf{3 . 9 7}$ & 0.93 \\
\hline $\begin{array}{l}\text { 9. Access to assessment procedures in } \\
\text { my institution's distance and online } \\
\text { platform is very easy. }\end{array}$ & $1(3.3)$ & $7(23.3)$ & $8(26.7)$ & $13(43.2)$ & $1(3 \cdot 3)$ & 3.20 & 0.96 \\
\hline $\begin{array}{l}\text { 10. I enjoy doing mathematics } \\
\text { assessment online. }\end{array}$ & $2(6.6)$ & $15(50.1)$ & $7(23.3)$ & $5(16.7)$ & $1(3.3)$ & 2.60 & 0.97 \\
\hline $\begin{array}{l}\text { 11. Assessment feedback is promptly } \\
\text { obtained online. }\end{array}$ & $3(10.0)$ & $9(30.0)$ & $8(26.7)$ & $9(30.0)$ & $1(3 \cdot 3)$ & 2.87 & 1.07 \\
\hline $\begin{array}{l}\text { 12. Distance and online assessment } \\
\text { procedures in my institution are very } \\
\text { effective. }\end{array}$ & $2(6.6)$ & $11(36.8)$ & $6(20.0)$ & $10(33.3)$ & $1(3.3)$ & 2.90 & 1.06 \\
\hline
\end{tabular}

Note. Boldface indicates significant responses. 
Table 2 centers on assessment practices as perceived among NOUN students. The mean score for "assessment procedures are well specified and included in the design of mathematics course materials in my institution" is relatively high $(M=3.80)$. This result shows that the students of NOUN agreed with their institution's assessment procedures. Similarly, the high mean scores for the items "It is better to use online and traditional procedures to assess distance and online mathematics students" $(M=4.07)$, "access to assessment procedures in my institution's distance and online platform is very easy" $(M=3.57)$, "I enjoy doing mathematics assessment online" ( $M=3.60)$, "assessment feedback is promptly obtained online" ( $M=3.63)$, and "distance and online assessment procedures in my institution are very effective" ( $M=3.57)$ show that distance and online mathematics learners in NOUN agreed with the assessment practices in their university. Nevertheless, the students disagreed with the following assertions: "There are no adequate resources to support student assessment procedures" $(M=2.97)$, "the guiding principle on mathematics assessment is not well understood by the students" ( $M=2.80)$, "the students' assessment guidelines involve too much paperwork (i.e., the traditional method of assessment) compared to distance and online activities" $(M=2.77)$, "online assessment of mathematics students is the only form of assessment procedure used in my institution" $(M=2.80)$, "my institution uses online and traditional assessment procedures in assessing the mathematics distance learners" $(M=3.40)$, and "I prefer traditional methods of assessment as opposed to online assessment" $(M=3.10)$.

These responses indicate that the learners need more resources, with clear and specific assessment principles to improve their mathematics learning experiences. 
Table 2. Responses of National Open University of Nigeria students as Related to Assessment Practices

\begin{tabular}{|c|c|c|c|c|c|c|c|}
\hline Questionnaire item & $\begin{array}{l}\text { Strongly } \\
\text { disagree }\end{array}$ & Disagree & Neutral & Agree & $\begin{array}{c}\text { Strongly } \\
\text { agree }\end{array}$ & $M$ & SD \\
\hline $\begin{array}{l}\text { 1. Assessment procedures are well } \\
\text { specified and included in the design } \\
\text { of mathematics course materials in } \\
\text { my institution. }\end{array}$ & 3 (10.0) & $1(3.3)$ & $5(16.7)$ & $11(36.7)$ & $10(33 \cdot 3)$ & 3.80 & 1.24 \\
\hline $\begin{array}{l}\text { 2. There are no adequate resources to } \\
\text { support student assessment } \\
\text { procedures. }\end{array}$ & $6(20.0)$ & $6(20.0)$ & $5(16.7)$ & $9(30.0)$ & $4(13 \cdot 3)$ & 2.97 & 1.38 \\
\hline $\begin{array}{l}\text { 3. The guiding principle on } \\
\text { mathematics assessment is not well } \\
\text { understood by the students. }\end{array}$ & $6(20.0)$ & $7(23 \cdot 3)$ & $8(26.7)$ & $5(16.7)$ & $4(13 \cdot 3)$ & 2.80 & 1.32 \\
\hline $\begin{array}{l}\text { 4. The students' assessment guidelines } \\
\text { involve too much paperwork (i.e. the } \\
\text { traditional method of assessment) } \\
\text { compared to distance and online } \\
\text { activities. }\end{array}$ & $5(16.7)$ & $7(23.3)$ & $9(30.0)$ & $8(26.7)$ & $1(3 \cdot 3)$ & 2.77 & 1.34 \\
\hline $\begin{array}{l}\text { 5. Online assessment of mathematics } \\
\text { students is the only form of } \\
\text { assessment procedure used in my } \\
\text { institution. }\end{array}$ & $5(16.7)$ & $9(30.0)$ & $5(16.7)$ & $9(30.0)$ & $2(6.6)$ & 2.80 & 1.24 \\
\hline $\begin{array}{l}\text { 6. My institution uses online and } \\
\text { traditional assessment procedures in } \\
\text { assessing the mathematics distance } \\
\text { learners. }\end{array}$ & $5(16.7)$ & $4(13 \cdot 3)$ & $1(3 \cdot 3)$ & $14(46.7)$ & $6(20.0)$ & 3.40 & 1.40 \\
\hline $\begin{array}{l}\text { 7. I prefer traditional methods of } \\
\text { assessment as opposed to online } \\
\text { assessment. }\end{array}$ & $2(6.6)$ & $6(20.0)$ & $13(43.4)$ & $5(16.7)$ & $4(13.3)$ & 3.10 & 1.09 \\
\hline $\begin{array}{l}\text { 8. It is better to use online and } \\
\text { traditional procedures to assess } \\
\text { distance and online mathematics } \\
\text { students. }\end{array}$ & $1(3 \cdot 3)$ & $2(6.6)$ & $2(6.6)$ & $14(46.7)$ & $11(36.8)$ & 4.07 & 1.02 \\
\hline $\begin{array}{l}\text { 9. Access to assessment procedures in } \\
\text { my institution's distance and online } \\
\text { platform is very easy. }\end{array}$ & $2(6.6)$ & 3 (10.0) & $8(26.7)$ & $10(33.4)$ & $7(23.3)$ & $\mathbf{3 . 5 7}$ & 1.17 \\
\hline $\begin{array}{l}\text { 10. I enjoy doing mathematics } \\
\text { assessment online. }\end{array}$ & $5(16.7)$ & $1(3.3)$ & $3(10.0)$ & $13(43.3)$ & $8(26.7)$ & 3.60 & 1.38 \\
\hline $\begin{array}{l}\text { 11. Assessment feedback is promptly } \\
\text { obtained online. }\end{array}$ & $2(6.6)$ & $4(13.3)$ & $4(13.3)$ & 13 43.4) & $7(24 \cdot 3)$ & 3.63 & 1.19 \\
\hline $\begin{array}{l}\text { 12. Distance and online assessment } \\
\text { procedures in my institution are very } \\
\text { effective. }\end{array}$ & $3(10.0)$ & $3(10.0)$ & $4(13 \cdot 3)$ & $14(46.7)$ & $6(20.0)$ & $\mathbf{3 \cdot 5 7}$ & 1.22 \\
\hline
\end{tabular}

Note. Boldface indicates significant responses. 
Reju \& Jita, 2020

Table 3. Assessment Practices in Distance Learning Institute (DLI) and National Open University of Nigeria (NOUN) Compared

\begin{tabular}{|c|c|c|c|c|}
\hline \multirow[b]{2}{*}{ Questionnaire item } & \multicolumn{2}{|c|}{ DLI } & \multicolumn{2}{|c|}{ NOUN } \\
\hline & $\boldsymbol{M}$ & $S D$ & $\boldsymbol{M}$ & $S D$ \\
\hline $\begin{array}{l}\text { 1. Assessment procedures are well specified and included in the } \\
\text { design of mathematics course materials in my institution. }\end{array}$ & 3.47 & .97 & 3.80 & 1.24 \\
\hline $\begin{array}{l}\text { 2. There are no adequate resources to support student assessment } \\
\text { procedures. }\end{array}$ & 2.93 & 1.11 & 2.97 & 1.38 \\
\hline $\begin{array}{l}\text { 3. The guiding principle on mathematics assessment is not well } \\
\text { understood by the students. }\end{array}$ & 2.87 & .86 & 2.80 & 1.32 \\
\hline $\begin{array}{l}\text { 4. The students' assessment guidelines involve too much paperwork } \\
\text { (i.e. the traditional method of assessment) compared to distance } \\
\text { and online activities. }\end{array}$ & 3.03 & 1.13 & 2.77 & 1.34 \\
\hline $\begin{array}{l}\text { 5. Online assessment of mathematics students is the only form of } \\
\text { assessment procedure used in my institution. }\end{array}$ & 2.43 & .94 & 2.80 & 1.24 \\
\hline $\begin{array}{l}\text { 6. My institution uses online and traditional assessment procedures } \\
\text { in assessing the mathematics distance learners. }\end{array}$ & 3.60 & 1.04 & 3.40 & 1.40 \\
\hline $\begin{array}{l}\text { 7. I prefer traditional methods of assessment as opposed to online } \\
\text { assessment. }\end{array}$ & 3.90 & .92 & 3.10 & 1.09 \\
\hline $\begin{array}{l}\text { 8. It is better to use online and traditional procedures to assess } \\
\text { distance and online mathematics students. }\end{array}$ & $\mathbf{3 . 9 7}$ & .93 & 4.07 & 1.02 \\
\hline $\begin{array}{l}\text { 9. Access to assessment procedures in my institution's distance and } \\
\text { online platform is very easy. }\end{array}$ & 3.20 & .96 & $\mathbf{3 . 5 7}$ & 1.17 \\
\hline 10. I enjoy doing mathematics assessment online. & 2.60 & .97 & 3.60 & 1.38 \\
\hline 11. Assessment feedback is promptly obtained online. & 2.87 & 1.07 & $\mathbf{3 . 6 3}$ & 1.19 \\
\hline $\begin{array}{l}\text { 12. Distance and online assessment procedures in my institution are } \\
\text { very effective. }\end{array}$ & 2.90 & 1.06 & $\mathbf{3 . 5 7}$ & 1.22 \\
\hline
\end{tabular}

Note. Boldface indicates significant responses.

Interestingly, similar positive responses for both DLI and NOUN mathematics students were seen on the item "It is better to use online and traditional procedures to assess distance and online mathematics students." The students saw a need to use online and traditional methods of assessment. Although NOUN students agreed on "there are well-specified assessment procedures," "easy access to assessment procedures," "enjoyment of doing mathematics assessment online," and "getting prompt feedback and effective assessment practices," DLI students were quite indifferent to all these assertions as shown in the mean scores. On the other hand, DLI students agreed that their "institution makes use of online and traditional assessment procedures, but the students prefer the traditional method of assessment as opposed to online method." The students in both institutions collectively disagreed with the following statements: "There are no adequate resources to support student assessment procedures," "the guiding principle on mathematics assessment is not well understood by the students," "the students' assessment guidelines involve too much paperwork (i.e., traditional method of assessment) compared to distance and online activities," and "online assessment of mathematics students is the only form of assessment procedure used in my institution." The mean scores of the students' responses in the two universities were below the acceptable mean score of 3.50. The findings show that even though the students need more resources, there are some measures of balance in the use of online and traditional methods of assessment procedures in these institutions. 
Reju \& Jita, 2020

\section{Qualitative Analysis}

The qualitative analysis was done to provide a deep understanding of assessment practices in DLI and NOUN. Assessment practices emerged as a major theme after subjecting the data to content analysis. The theme further gave rise to three subthemes: assessment practices in DLI and NOUN, preferences to assessment practices, and peculiar challenges of online assessment. These are discussed in detail below.

\section{Assessment Practices in DLI and NOUN}

Variations were observed pertaining to the students' responses in assessment practices in DLI and NOUN. The mathematics students from the institutions indicated availability and usage of both online and traditional pen-on-paper (POP) mode of assessment in their schools. In a student's words: "Yes, my institution makes use of both traditional and online assessment."

While there are no specified procedures of online and traditional assessment in DLI, however, NOUN students revealed a unique dimension to assessment practices in their institution. Virtually all the students of NOUN commented that online assessment takes place in the first and second years of their university mathematics education, whereas POP is used as of the third year. As commented by a NOUN student,

Yea, our assessment is always online. For those in 100 and 200 (lower) levels, their mode of assessment is only online but from 300 level upward, pen on paper are used all through. I think that arrangement is good because it will help you to know how to write and solve mathematics problems on paper not just answering questions online.

This expression is quite different from the experiences of students in DLI. One of them commented, "We do some assessment online and some through traditional means. We encounter lots of difficulties submitting assignments online."

\section{Preferences to Assessment Practices}

There are some mixed reactions from the narratives of the students concerning preferences to assessment practices in both DLI and NOUN. While some preferred online assessment mode, the majority stated that the traditional POP mode of assessment is the best. The reason being that the traditional assessment mode allows them to express their mathematical knowledge and skills on paper. For example, a DLI student's opinion was captured thus:

Hmmm, the two modes of assessment (online and traditional) are okay, but I still prefer the traditional way of coming to class and assessing us, it saves us from the stress and difficulty we experience in log-in, typing the mathematical functions and online submission.

A similar opinion expressed by a NOUN mathematics education student was captured as follows:

I think online and traditional assessment are both good, I prefer them both because they test different skills in a student. Online assessment though faster and easier for me but it is easier for anyone to know the real mathematical skill in me when I am being assessed in the traditional mode. Online is programmed and it is not enough to assess mathematical skills in me, so I prefer the traditional assessment in that regard.

The learners in NOUN echoed satisfaction for the modes of assessment in their institution which is based on using online assessment mode for first- and second-year students, whereas studnets in the third year and beyond are being assessed using POP or traditional modes. This can be seen from the comment, "I can say 
Reju \& Jita, 2020

that assessment mode in NOUN is effective, I like it." Hence, the assessment structure witnessed in NOUN is more defined unlike the experiences at DLI.

\section{Peculiar Challenges of Online Assessment}

The reported responses among DLI students showed that they are demotivated with assessment practices in their institution. They stressed that the systems of getting feedback on assessments and examinations are not yet effective. The opinion of one student was captured thus:

I think they have a lot to do in the area of giving feedback on assessment to the students. I thought the feedback on either assessment or examination will be instant or immediate, but there is nothing like that. It takes ages to get feedback in any assessment you do here. In fact, there is no difference between you studying through ODL and those in the traditional mode of learning when it comes to getting feedback.

Also, the students in both DLI and NOUN lamented that poor Internet connectivity and availability constituted a big challenge hindering the online login and submission of assessments. Though the situation is minimal among NOUN respondents, one of the DLI students commented, "I have difficulties in submitting assessment online because I cannot at any time I want (to) go online due to lack of Internet connectivity."

Furthermore, NOUN students appeared to be pleased with the way assessment feedback is handled in their school. One of the students commented that

aside (from) providing our own Internet when studying outside the school environment and poor connectivity witnessed sometimes, I can tell you that the online quiz we do in my school is very effective. The assessment mode I will say is okay, in the sense that we easily submit the assessment online with minimal hindrances and receive feedback accordingly in a good time.

Another student also stated that "due to the way the assessment is organized, confidence has been built in us to solve mathematics problems. It's very okay.”

\section{Discussion}

The findings of this study provide a valuable snapshot of assessment practices in DLI and NOUN. The participants' responses in both quantitative and qualitative analyses indicated the existence of both similarities and variations in the mode of assessment practices among these ODL institutions. The main outstanding similarity witnessed in this study shows that the universities have initiated the use of online and traditional methods of assessing the students instead of focusing on just one method. The students also expressed similar opinions on the preference of traditional mode of assessment over online mode. The important reason being that the traditional form of assessment allows them to express their mathematical skills on paper freely for their tutors to discover the extent of mathematical knowledge they have. This corroborates a similar finding to that of Holmes (2014), who found that the "students preferred traditional method of assessment but stated that the online assessments are used to reinforce knowledge... however, if the computer goes wrong or if your Internet connection dies, they can be painful” (p. 8). Nevertheless, the students' preference for traditional assessment practice does not support the opinion of Baleni (2015), who stated that assessing students using technologies is very effective and efficient. Moreover, a similar challenge, in terms of availability and connectivity of the Internet can be observed among the institutions used in this study. The DLI students especially lamented their inability to access internet for their studies, confirms Ohene and Essuman (2014) assertion that the cost of accessing the Internet is still very high in most African 
countries compared to developed countries. Hence, the quantitative and qualitative results showed that the participants need better access to resources (Internet) for effective mathematics learning.

The disparity witnessed in assessment practices in DLI and NOUN can be linked to Kissane et al. (2015) assertion that institutions are responsible for their own assessment practices. From the evidence provided by the participants, assessment practices seem to be more organized at NOUN than at DLI where online assessment procedures are strictly enforced for the students in first and second years of study, and the traditional mode of assessment seems to dominate in the third till the final years of the program. However, the variant of assessment practices in NOUN, for different levels of students, is an interesting development that has not been explored as much in the literature of distance and online education.

To ensure quality and flexible assessment practices, Sagarraa and Zapataa (2008) pointed out feedback on work done as one of the features of online assessment. DLI students in this study seem not to be satisfied with the manner the feedback is given. They lamented waiting for "ages" to receive feedback on their assessments and examinations. This scenario contributed to students' shifting their preference to traditional assessment over online assessment. One of them stressed, "I prefer pen and paper assessment if there would be no feedback for the online assessment." The students in NOUN are more satisfied with the assessment mode and the process of obtaining feedback in their school. Hence, the respondents indicated that online and traditional modes of assessment in their institution are very effective.

\section{Conclusion and Recommendation}

This study investigated and found similarities and variations in assessment practices among distance and online mathematics learners from two ODL institutions in Nigeria. The study revealed that the ODL institutions used in this study employ traditional and online modes of assessment practices. Though the students admitted that each of the modes has its own associated advantages, the traditional assessment was preferred. This assertion is similar to the findings of (Baleni, 2015). It is also clear that the students' preference for a traditional form of assessment stemmed from the opportunity they have to express their mathematical knowledge and skills on paper. This opportunity could as well be incorporated in the design of the school's choice learning management system by making the platform more interactive necessary in meeting individual student learning needs. It is known that distance and online learning depends heavily on technology, with Internet access being an important determining factor. Fast and reliable access to the Internet is thus essential for the learners to be effectively assessed during their studies.

The DLI participants indicated that the prompt feedback on their assessment is lacking, resulting in their expectations not being met. One of them commented that "There is no feedback from the tutors when we do assignment online, it is so frustrating." Mampane (2015) claimed that the students rely on feedback to measure their learning progress, was not completely true in this study especially among DLI mathematics distance and online learners. In the case of NOUN learners, confidence in doing mathematics through distance and online mode has been built in them through well-defined and organized assessment structure. To ensure quality and flexible assessment practices in ODL institutions in Nigeria, it is therefore vital to provide viable Internet connectivity, alongside regular and exact feedback to the learners. There is also a need for creation of strong practical and online interactive sessions that will interest and attract students learning mathematics through this mode. DLI and NOUN are public institutions whose operations are dependent on the financial supports of the government in Nigeria; therefore, the problem of limited resources for assessing the students could be solved by the institutions collaborating with the government to provide these resources. These will help to improve the students' mathematics learning experiences. The varied assessment practices in NOUN for different levels of students witnessed in this study are a useful development that can be explored further, through systematic research to unfold reasons why it is so. A limitation in this study emanated from the fact that all the participants were third year undergraduate mathematics students with ODL mode of the 
learning experience. These are not entirely representative of the whole mathematics learner population in DLI and NOUN; hence, the findings may not be generalized but are applied only to ODL institutions with similar characteristics.

\section{References}

American Mathematical Association of Two-Year Colleges. (2018). IMPACT: Improving mathematical prowess and college teaching.

Baleni, Z. G. (2015). Online formative assessment in higher education: Its pros and cons. The Electronic Journal of e-Learning, 13(4), 228-236.

Bull, J., \& McKenna, C. (2004). Blueprint for computer-assisted assessment. Routledge Flamer.

Camacho-Miñano, M., Campo, C., Ezama, D. P., Rivero, C., Grande, E. U., \& Akpinar, M. (2013). Is the EHEA evaluation criteria optimum? Empirical evidence from Finland and Spain. Interdisciplinary Studies Journal, 2(3), 101-117.

Chaudhary, S. V. S., \& Dey, N. (2013). Assessment in open and distance learning system (ODL): A challenge. Open Praxis, 5(3), 207-216.

Cohen, L., Manion, L., \& Morrison, K. (2007). Research methods in education (6th ed.). Routledge.

Creswell, J. W. (2014). Research design: Qualitative, quantitative and mixed methods approach (4th ed.). Sage.

Elo, S., \& Kyngäs, H. (2008). The qualitative content analysis process. Journal of Advanced Nursing, 62(1), 107-115.

Holmes, N. (2014). Student perceptions of their learning and engagement in response to the use of a continuous e-assessment in an undergraduate module. Assessment and Evaluation in Higher Education, 4O(1), 1-14.

Kissane, B., McConney, A., \& Ho, K. F. (2015). Review of the use of technology in mathematics education and the related use of CAS calculators in external examinations and in post-school tertiary education settings. School Curriculum and Standards Authority.

Mampane, M. R. (2015). Assessment in open and distance learning. In M. Letseka (Ed.), Open distance learning (ODL) in South Africa (pp. 39-50). Nova Science Publishers.

Morris, D. (2008). Economics of scale and scope in e-learning. Teaching in Higher Education, 33(3), 331343 .

Ohene, J. B., \& Essuman, S. O. (2014). Challenges faced by distance education students of the University of Education, Winneba: Implications for strategic planning. Journal of Education and Training, 1(2), 156-176.

Ozerbas, M. A., \& Erdogan, B. H. (2016). The effect of the digital classroom on academic success and online technologies self-efficacy. Educational Technology \& Society, 19(4), 203-212.

Perera-Diltz, D. M., \& Moe, J. L. (2014). Formative and summative assessment in online education. Journal of Research in Innovative Teaching, 7(1). 130-142.

Ramsden, P. (1991). A Performance indicator of teaching quality in higher education: The Course Experience Questionnaire. Studies in Higher Education, 16(2), 129-149. 
Reju, C. O. (2016). Students' experiences with distance and online learning of university-level undergraduate in Nigeria (Doctoral thesis). http://scholar.ufs.ac.za:8080/xmlui/bitstream/handle/11660/5387/RejuCO.pdf?sequence=1

Sagarraa, N., \& Zapataa, G. C. (2008). Blending classroom instruction with online homework: A study of student perceptions of computer-assisted L2 learning. European Association for Computer Assisted Language Learning, 2O(2), 208-224.

Sorensen, E. (2013). Implementation and student perceptions of e-assessment in a chemical engineering module. European Journal of Engineering Education, 38(2), 172-185.

Stacey, K., \& Wiliam, D. (2013). Technology and assessment in mathematics. In A. J. Bishop, M. A. Clements, C. Keitel, J. Kilpatrick, \& F. K. S. Leung (Eds.), Third International handbook of mathematics education (pp. 721-751). Springer.

Suurtamm, C., Kim, R. Y., Diaz, L., \& Sayac, N. (2016). Assessment in mathematics education: ICME-13 topical surveys. Springer.

The Ministry of Human Resources Department. (2019). Draft national education policy. Shastri Bhavan.

Trenholm, S., Alcock, L., \& Robinson, C. (2015). An investigation of assessment and feedback practices in fully asynchronous online undergraduate mathematics courses. International Journal of Mathematical Education in Science and Technology, 46(8), 1197-1221.

U.S. Department of Education, Office of Educational Technology. (2017). Reimagining the role of technology in education: National Education Technology Plan update.

Yushau, B., \& Khan, M. A. (2014). Student perceptions of online homework in preparatory year pre-calculus courses. International Journal of Mathematics Trends and Technology, 8(1), 12-17.

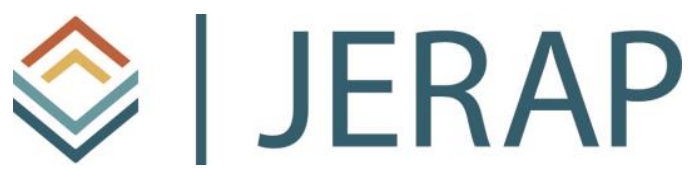

The Journal of Educational Research and Practice is a peerreviewed journal that provides a forum for studies and dialogue about developments and change in the field of education and learning. The journal includes research and related content that examine current relevant educational issues and processes. The aim is to provide readers with knowledge and with strategies to use that knowledge in educational or learning environments. JERAP focuses on education at all levels and in any setting, and includes peer-reviewed research reports, commentaries, book reviews, interviews of prominent individuals, and reports about educational practice. The journal is sponsored by the Richard W. Riley College of Education and Leadership at Walden University, and publication in JERAP is always free to authors and readers. 